\title{
Climate Change Impacts During Near, Mid and End Century Over Rice Bowl of Tamil Nadu, India
}

\author{
P. Shajeesh Jan*, S. Paneerselvam, V. Geethalakshmi, Ga. Dheebakaran, \\ K.P. Ragunath, and R. Jagannathan
}

Agro Climate Research Centre, Tamil Nadu Agricultural University, Coimbatore, Tamil Nadu, India

*Corresponding author

\begin{tabular}{|c|c|}
\hline & A B S T R A $\mathbf{C}$ \\
\hline & \multirow{6}{*}{$\begin{array}{l}\text { The study utilized two downscaled climate model (GFDL-ESM2M and HadGEM2-ES) } \\
\text { outputs from Agro Climate Research Centre, Tamil Nadu for the Representative } \\
\text { Concentration Pathways } 4.5 \text { and } 8.5 \text { using regional climate model namely RegCM } 4.4 \text {. The } \\
\text { model output was fed into DSSAT crop simulation for assessing vulnerability of rice crop } \\
\text { to projected climate change for near, mid and end of century. The study revealed an } \\
\text { increase of maximum temperature for near }\left(0.8 \text { to } 1.2^{0} \mathrm{C}\right) \text { mid }\left(1.3 \text { to } 2.5^{\circ} \mathrm{C}\right) \text { and end }(1.5 \text { to } \\
\left.4.2^{0} \mathrm{C}\right) \text { of century while increase of minimum temperature for near }\left(0.7-1.2^{0} \mathrm{C}\right) \text { mid }(1.3 \text { to } \\
\left.2.6^{0} \mathrm{C}\right) \text { and end }\left(1.6-4.5^{0} \mathrm{C}\right) \text { century. The rainfall projected was highly variable as indicated } \\
\text { by high RMSE value of } 117.06 \text { and also showed that rainfall was more for GFDL-ESM } 2 \mathrm{M} \\
\text { model and less for HadGEM } 2-\mathrm{ES} \text { model over the time period. The relative difference of } \\
\text { rice yield indicated that in RCP } 4.5 \text {, highest reduction was observed for end of century }(- \\
8.6 \text { to }-22.1 \%) \text { followed by mid }(-2.2 \text { to } 21.1 \%) \text { and near }(+0.1 \text { to }-9.1 \%) \text { while for RCP } \\
8.5, \text { highest reduction was seen during mid }(-17.7 \text { to }-20.5 \%) \text { followed by end }(-11.9 \text { to }- \\
16.3 \%) \text { and near }(-9.6 \text { to } 13.6 \%) \text { century. }\end{array}$} \\
\hline Keywords & \\
\hline $\begin{array}{l}\text { Climate change, } \\
\text { RegCM and RCP. }\end{array}$ & \\
\hline Article Info & \\
\hline $\begin{array}{l}\text { Accepted: } \\
17 \text { October } 2017 \\
\text { Available Online: } \\
10 \text { December } 2017\end{array}$ & \\
\hline & \\
\hline
\end{tabular}

\section{Introduction}

Crop production systems are often largely controlled by environmental factors, thus being vulnerable to climate change (IPCC, 2013). Thanjavur district of Tamil Nadu is popularly known as rice bowl of Tamil Nadu.

The studies on projecting the future climate under projected climate change scenarios and its impacts on rice productivity over Thanjvaur district is much important for arriving adaptation strategies in view of better rice production and food security of Tamil Nadu state.

\section{Study area}

Thanjavur bounded by $10.99^{\circ} \mathrm{N}$ latitude, $79.47^{\circ} \mathrm{E}$ longitude and $11.02^{\circ} \mathrm{N}$ latitude, $79.49^{\circ} \mathrm{E}$ longitude (Figure 1). The soils of Thanjavur district are potentially productive.

\section{Study period}

For projecting future climate change and its impact on rice yield, the dynamically downscaled historic base line data for the period 1971-2005 and future data for the period 2010-2100, under two Representative Concentration Pathway (RCP) scenarios such as RCP 4.5 and RCP 8.5 were used. 


\section{Regional climate model (RegCM4.4)}

The dynamical downscaling was done at Agro Climate Research Centre (ACRC), Tamil Nadu Agricultural University (TNAU), Coimbatore, employing Regional Climate Model (RCM) RegCM4.4 and the products were used for the study.

\section{Calibration of CERES rice crop simulation model}

CERES Rice model was calibrated for popular rice variety $\mathrm{CO}(\mathrm{R}) 50$ by iteration method for assessing the impact of projected climate change on yield of Samba rice crop in Thanjavur district of Tamil Nadu. The genetic coefficient estimated is given in the Table 1 .

\section{Climate change impact assessment}

Impact assessment of climate change on rice production was carried out by downscaling of two GCM models GFDL-ESM2M, HadGEM2-ES using regional climate model namely RegCM4.4. The downscaling for future climate change was done for the period 2006-2100 under 4.5 and 8.5 RCP scenarios. A historical run was also carried out for above two models for obtaining base year data for the period of 1971-2005.

The daily weather variables such as maximum temperature, minimum temperature, rainfall and solar radiation were used for the historical run whereas for the future period, three time scales such as near century(2010-2039), mid (2040-2069)century and end century(20702100) derived from model output under two RCP scenarios were fed into DSSAT 4.6 crop simulation model. The carbon dioxide concentration for climate scenarios and time period prescribed for use in crop simulation model by Rosenzweig et al., (2016) is given Table 2.

\section{Verification of climate data}

Verification of climate data was done using CRU gridded data with the following statistical techniques.

The error statistics viz. Mean absolute Deviation (MAD), Root Mean Square Error (RMSE), Mean Absolute Percentage Error (MAPE) along with correlation coefficient (r) were estimated for verification CRU with projected data and the equations used for the analysis is given below.

Mean Absolute Deviation (MAD)

$M A D=\frac{\sum_{i=1}^{n}(O i-P i)}{n}$

Root Mean Squire Error (RMSE)

RMSE $=\sqrt{\frac{\sum_{i=1}^{n}(O i-P i)^{2}}{n}}$

Mean Absolute Percentage Error

MAPE $=\frac{\sum_{i=1}^{n} \frac{|O i-P i|}{|O i|}}{n} \times 100$

\section{Correlation coefficient (r)}

$$
r=\frac{\sum P i O i \frac{\sum P i \cdot \sum O i}{n}}{\sqrt{\sum P i^{2}-\frac{\left(\sum P i\right)^{2}}{n}} \cdot \sqrt{\sum O i^{2}-\frac{\left(\sum O i\right)^{2}}{n}}}
$$

Where,

$\mathrm{P}_{\mathrm{i}}$ is the predicted data, $\mathrm{O}_{\mathrm{i}}$ represent observed data. $\mathrm{n}$ is the number of observation 


\section{Percentage relative difference (R.D. \%)}

Percentage relative difference from base year (1971-2005) for rice productivity was worked out for near century (2010-2039), mid-century (2040-2069) and end of century (2070-2100) using the following formula.

R.D. $\%=\frac{\frac{\text { Average predicted future years-Average predicted base years }}{\text { Average predisted base years }}}{\text { ans }}$

\section{Results and Discussion}

\section{Validation of climate change projection}

Monthly mean downscaled baseline data (1971-2005) were validated with climatic research Unit (CRU) observed data using statistical techniques viz., Mean Absolute Difference (MAD), Root Mean Squire Error (RMSE), Mean Absolute Percentage Error (MAPE) and correlation coefficient (Table 3). The results inferred that, for maximum and minimum temperature the statistical results was appreciable and indicated prediction was valid. The high level of correlation coefficients irrespective of models suggested its reliability. In the case of rainfall, the model variability was high with lower correlation (0.32) and higher RMSE (172.51) and while analysing the data it was revealed that, GFDL models overestimated rainfall in this region whereas HadGEM2 underestimated rainfall. This result goes in tally with Dash et al., 2014 where he founded out HadGEM2 underestimated rainfall over most parts of India except Western Ghats and Arunachal Pradesh.

\section{Climate projections}

The downscaled daily data (maximum temperature, minimum temperature and rainfall) of two GCM models GFDLESM2M, HadGEM2 were averaged to grid point pertaining to Thanjavur district and time period was classified for near (2011 - 2039), mid (2040-2069) and end (2070-2099) century and the deviation from the timescales to that of base years (1971-2005) were worked out to understand the projected change.

\section{Deviation of maximum temperature for Thanjavur district}

The maximum temperature over Thanjavur district was projected to be increasing by the two models used for the study. The results also revealed that, increase of temperature was more in HadGEM2 projection compared to GFDL-ESM2M and maximum increase was noted for end of the century (2070-2100) for both RCP 4.5 and RCP 8.5 scenarios. For HadGEM2 during end of century, an increase of $2.5^{\circ} \mathrm{C}$ and $4.2^{\circ} \mathrm{C}$ was projected for RCP 4.5 and RCP 8.5 respectively while the GFDLESM2M projected increase for the same period was $1.5^{\circ} \mathrm{C}$ and $2.8^{\circ} \mathrm{C}$ for RCP 4.5 and RCP 8.5 respectively. Geethalakshmi et al., (2011) also found out impacts of climate change on in Cauvery delta basin of Tamil Nadu for A1B scenario and concluded an increasing trend for maximum, minimum temperatures and rainfall (Table 4).

\section{Deviation of minimum temperature for Thanjavur district}

The projection of minimum temperature over Thanjavur district of Tamil Nadu showed a grater increase of night temperature from near to end of century. Similar to maximum temperature, HadGEM2 projected higher minimum temperature than GFDL-ESM2M. For RCP 4.5 and 8.5 scenarios, the HadGEM2 projected an increase of minimum temperature from near to end of century as $1.0^{\circ} \mathrm{C}$ to $2.5^{\circ} \mathrm{C}$ and $1.2^{\circ} \mathrm{C}$ to $4.4^{0} \mathrm{C}$ respectively whereas for GFDL-ESM2M projected increase for the same period was $0.7^{0} \mathrm{C}$ to $1.6^{\circ} \mathrm{C}$ and $1.0^{\circ} \mathrm{C}$ to $3.1^{\circ} \mathrm{C}$ (Table 5). 
Fig.1 Location map of Kuttanad region

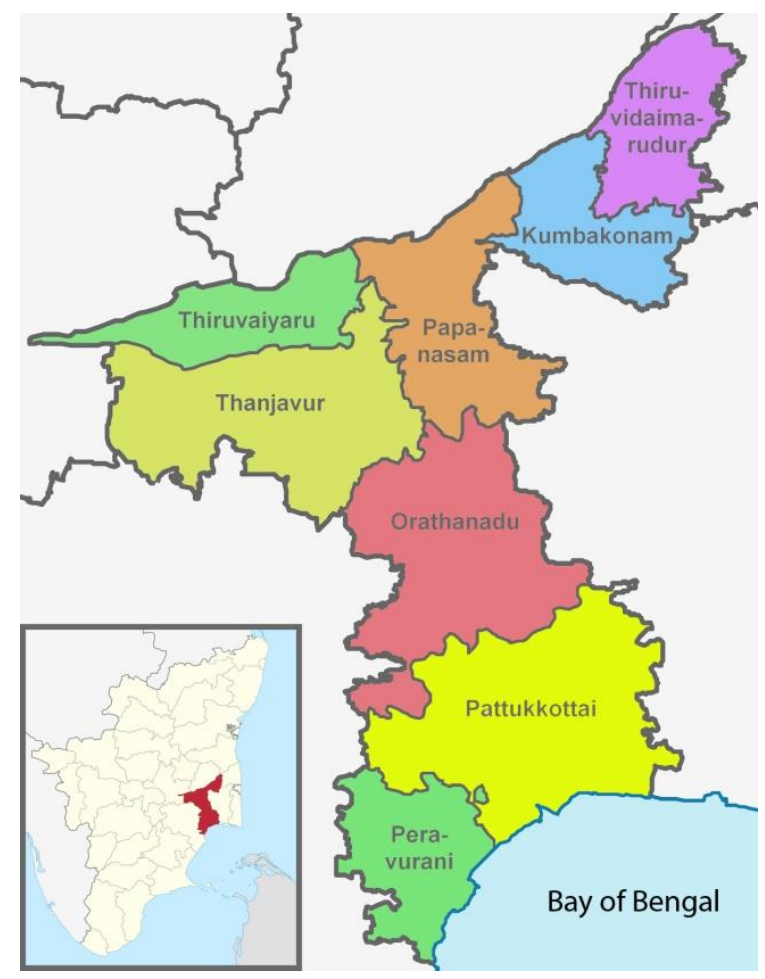

Fig.2 Percent relative difference of rice yield over Thanjavur under RCP 8.5 scenario

\section{Percent relative difference of rice yield over Thanjavur under RCP 8.5 scenario}

\section{GEDL-ESM2M DHadGEM2}

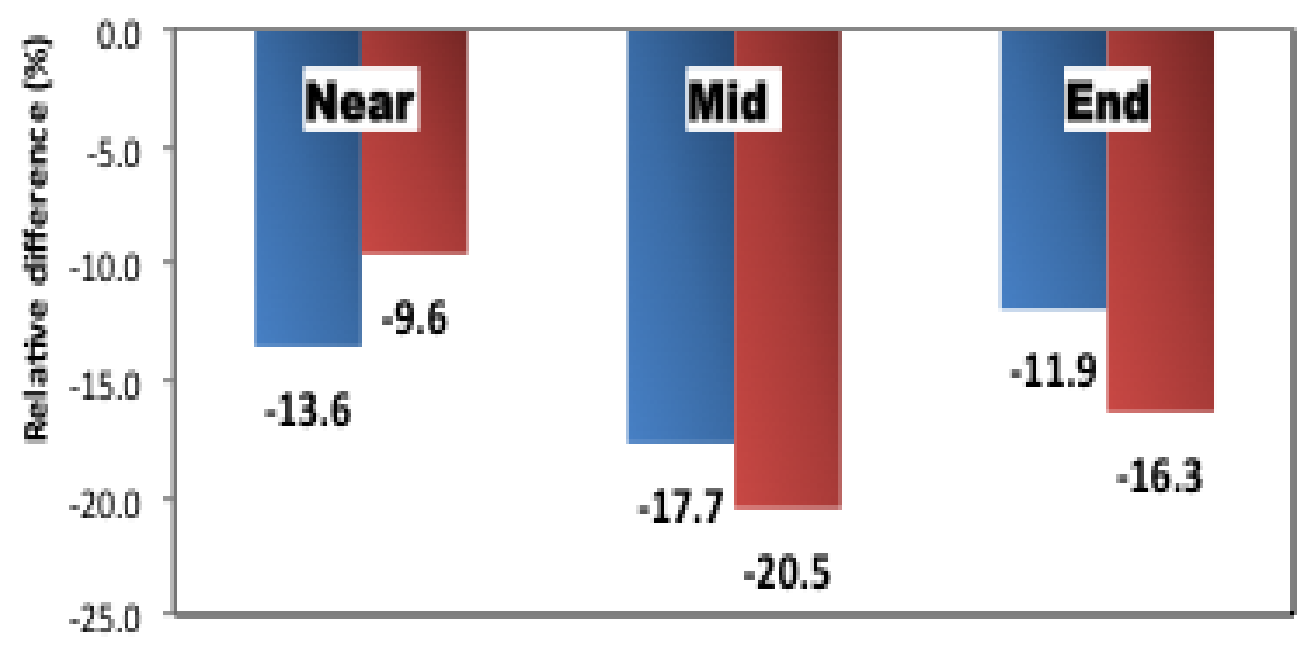


Fig.3 Percent relative difference of rice yield over Thanjavur under RCP 4.5 scenario

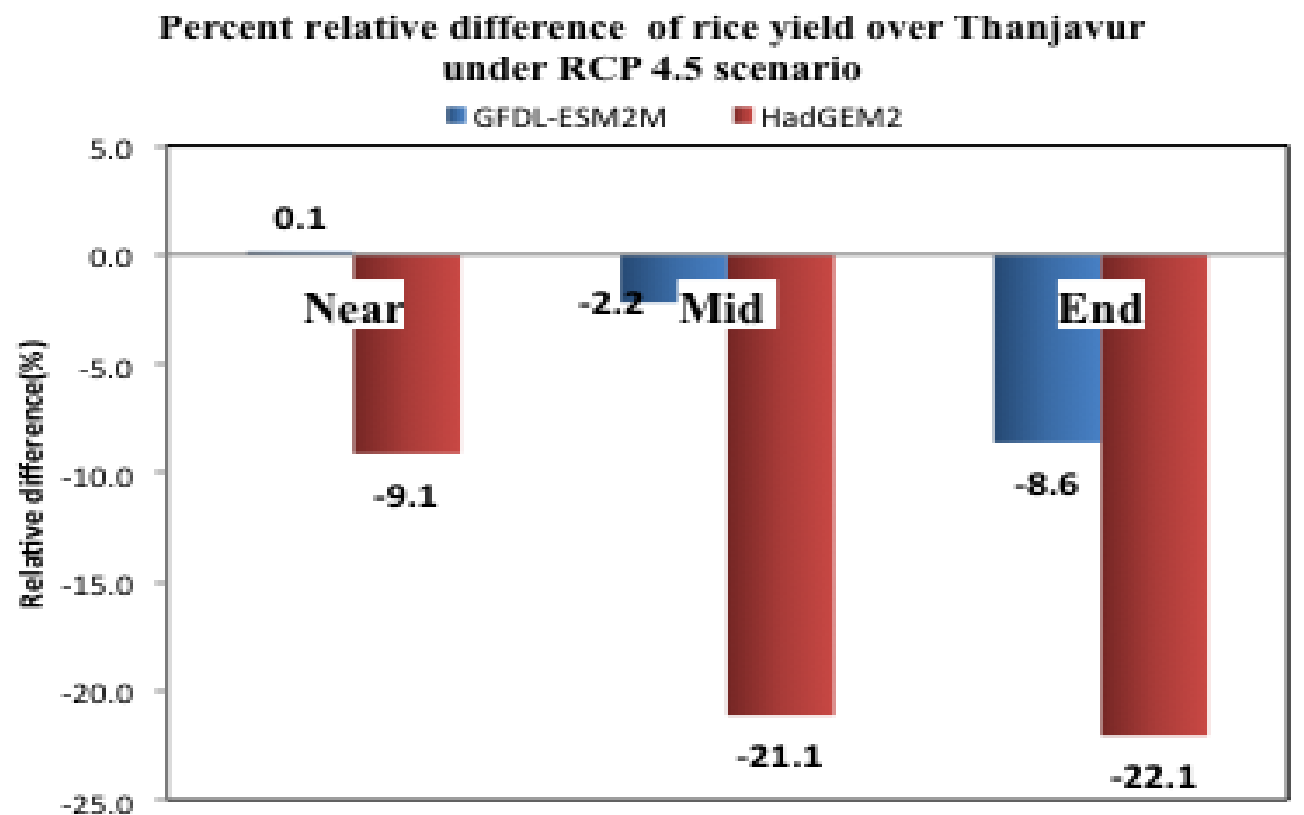

Table.1 Genetic coefficient for $\mathrm{CO}(\mathrm{R}) 50$ rice variety for CERES rice model

\begin{tabular}{|l|l|l|l|l|l|l|l|}
\hline P1 & P2R & P5 & P20 & G1 & G2 & G3 & G4 \\
\hline 550.7 & 83.4 & 315.3 & 12 & 58 & 0.02 & 1 & 1 \\
\hline
\end{tabular}

Table.2 The $\mathrm{CO}_{2}$ increment in ppm over the study period

\begin{tabular}{|l|l|l|}
\hline \multicolumn{1}{|c|}{ Scenario } & Time Period & {$\left[\mathbf{C O}_{2}\right]$} \\
\hline Current & $1971-2005$ & 380 \\
\hline RCP4.5 Near-term & $2010-2039$ & 423 \\
\hline RCP8.5 Near-term & $2010-2039$ & 432 \\
\hline RCP4.5 Mid-Century & $2040-2069$ & 499 \\
\hline RCP8.5 Mid-Century & $2040-2069$ & 571 \\
\hline RCP4.5 End-of-Century & $2070-2100$ & 532 \\
\hline RCP8.5 End-of-Century & $2070-2100$ & 801 \\
\hline
\end{tabular}

Table.3 Validation of climate change projections

\begin{tabular}{|l|l|r|r|r|r|}
\hline Model & & MAD & MAPE & RMSE & R \\
\hline \multirow{3}{*}{ GFDL-ESM2M } & Maximum temperature & 2.26 & 6.88 & 2.54 & 0.88 \\
\cline { 2 - 6 } & Minimum temperature & 5.20 & 21.04 & 19.60 & 0.91 \\
\cline { 2 - 6 } & Rainfall & 113.66 & 229.97 & 172.51 & 0.32 \\
\hline \multirow{3}{*}{ HadGEM2-ES } & Maximum temperature & 1.17 & 3.55 & 1.34 & 0.86 \\
\cline { 2 - 6 } & Minimum temperature & 4.65 & 18.70 & 4.72 & 0.89 \\
\cline { 2 - 6 } & Rainfall & 78.10 & 121.80 & 117.06 & 0.38 \\
\hline
\end{tabular}


Table.4 Deviation of maximum temperature projection for Thanjavur district

\begin{tabular}{|l|l|l|l|l|}
\hline & \multicolumn{2}{|c|}{ RCP 4.5 } & \multicolumn{2}{c|}{ RCP 8.5 } \\
\hline & GFDL-ESM2M & HadGEM2 & GFDL-ESM2M & HadGEM2 \\
\hline $2010-2039$ & 0.8 & 1.1 & 0.90 & 1.2 \\
\hline $2040-2069$ & 1.3 & 1.9 & 1.9 & 2.5 \\
\hline $2070-2100$ & 1.5 & 2.5 & 2.8 & 4.2 \\
\hline
\end{tabular}

Table.5 Deviation of minimum temperature projection for Thanjavur district

\begin{tabular}{|l|l|l|l|l|}
\hline & \multicolumn{2}{|c|}{ RCP 4.5 } & \multicolumn{2}{c|}{ RCP 8.5 } \\
\hline & GFDL-ESM2M & HadGEM2 & GFDL-ESM2M & HadGEM2 \\
\hline $2010-2039$ & 0.7 & 1.0 & 1.0 & 1.2 \\
\hline $2040-2069$ & 1.3 & 1.9 & 2.0 & 2.6 \\
\hline $2070-2100$ & 1.6 & 2.5 & 3.1 & 4.4 \\
\hline
\end{tabular}

Table.6 Deviation of rainfall projection for Thanjavur district

\begin{tabular}{|l|l|l|l|l|}
\hline & \multicolumn{2}{|c|}{ RCP 4.5 } & \multicolumn{2}{c|}{ RCP 8.5 } \\
\hline & GFDL-ESM2M & HadGEM2 & GFDL-ESM2M & HadGEM2 \\
\hline $2010-2039$ & 75 & -86 & 101 & 18 \\
\hline $2040-2069$ & 118 & -83 & 43 & -125 \\
\hline $2070-2100$ & 119 & -71 & 98 & -243 \\
\hline
\end{tabular}

Deviation of rainfall projection for Thanjavur district

The tri-decadal rainfall projection for Thanjavur district of Tamil Nadu inferred that, the two models projected rainfall differently. The GFDL-ESM2M projected an increase of rainfall for near, mid and end century for both RCPs while in HadGEM2, the rainfall was decreasing for all the time scales for RCP 4.5 and for RCP 8.5 scenarios, showed an increase for near century after that it was decreasing (Table 6).

Impact of rice production to future climate change

DSSAT crop simulation model was used to assess the impact of rice to future climate change and the results were shown in Figure.
The percent deviation of rice productivity from base year (1971-2005) in Thanjavur district of Tamil Nadu revealed a yield reduction for all the time period under RCP 8.5 scenario (Figure 2). The results also indicated that reduction in yield was maximum for mid-century at which a decrease of $17.7 \%$ and $20.5 \%$ was noticed for GFDL-ESM2M and HadGEM2 respectively. The yield reduction was maximum for HadGEM2 model except during near century. The reduction in yield was decreased during in end of century for both models.

The percent relative difference of Thanjavur rice yield for RCP 4.5 revealed reduction from near century to end of century (Figure $3)$. The highest yield reduction was observed during end century followed by mid-century and near century. In this period, the reduction 
in rice yield when compared to baseline period (1971-2005) was $-22.1 \%$ for HadGEM2 and $-8.6 \%$ for GFDL-ESM2M while variability during mid-century varied between $-21.1 \%$ for HadGEM 2 and $-2.2 \%$ for GFDL-ESM2M. The relative difference for near century was negligible $(+1 \%)$ for GFDLESM2M when compared HadGEM2 (-9.1\%). Rajalakshmi et al., (2015) also assessed influence of projected climate on rice yield over Tamil Nadu using PRECIS and RegCM4 Regional Climate Models (RCMs) for the period from 2011 to 2100 and revealed a 10 $\%$ decline in rice productivity by the end of the $21^{\text {st }}$ century, relative to the average yield during the base period 1971-2009.

The study predicted significant decline in rice productivity over rice bowl of Tamil Nadu state. The yield reduction varied over time scale and scenario used and yield reduction up to $22 \%$ was observed. The study also gave an insight of a significant increase of maximum and minimum temperature and variability of rainfall under the projected climate change scenarios.

\section{References}

Dash, S.K., K. C. Pattnayak, S. K. Panda, Deepika Vaddi, Ashu Mamgain. 2014. Impact of domain size on the simulation of Indian summer monsoon in RegCM4 using mixed convection scheme and driven by HadGEM2. Clim. Dyn.,
Geethalakshmi, V., Lakshmanan, A., Rajalakshmi, D., Jagannathan, R., Gummidi S., Ramaraj, AP., Bhuvaneswari, KL. Gurusamy and R. Anbhazhagan, 2011. 'Climate change impact assessment and adaptation strategies to sustain rice production in Cauvery basin of Tamil Nadu', Current Science, 101(3): 342-347

IPCC, 2013. In: Stocker, T.F., Qin, D., Plattner, G.-K., Tignor, M., Allen, S.K., Boschung, J., Nauels, A., Xia, Y., Bex, V., Midgley, P.M. (Eds.). The physical science basis. Contribution of working group I to the fifth assessment report of the intergovernmental panel on climate change. Cambridge University Press, Cambridge, United Kingdom and New York, NY, USA, pp. 1-1535.

Rajalakshmi, D., Jagannathan, R., and Geethalakshmi, V. 2015. Influence of Projected Climate on Rice Yield Over Tamilnadu. Indian Journal of Science and Technology, 8(11). https://doi.org/ 10.17485/ijst/2015/v8i11/71801

Rosenzweig, C., J.W. Jones, J. Hatfield, J.M. Antle, A.C. Ruane, K.J. Boote, P. Thorburn, R.O. Valdivia, K. Descheemaeker, C.H. Porter, S. Janssen, W. Bartels, A. Sulivan, and C.Z. Mutter. 2016. Protocols for AgMIP Regional Integrated Assessments Version 6.1.

\section{How to cite this article:}

Shajeesh Jan, P., S. Paneerselvam, V. Geethalakshmi, Ga. Dheebakaran, K.P. Ragunath, and Jagannathan, R. 2017. Climate Change Impacts During Near, Mid and End Century Over Rice Bowl of Tamil Nadu. Int.J.Curr.Microbiol.App.Sci. 6(12): 2407-2413. doi: https://doi.org/10.20546/ijcmas.2017.612.278 